\title{
Research on Work Model of Ideological and Political Education in Enterprises as Human Resource Business Partner
}

\author{
Tan Shuai, Zheng Yong'an \\ School of Humanities, Economics and Law, \\ Northwestern Polytechnical University, Xi'an, 710072, PR China \\ tanshuai710072@126.com
}

Keywords: Ideological and political education; Human resource management; System model

\begin{abstract}
By analyzing the relationship between the ideological and political education and human resource management under the modern enterprise system, this paper constructs the work model of the ideological and political education as the human resource management partner with the focus on how to serve the implementation of organization strategy and establish relevant system model.
\end{abstract}

\section{Introduction}

China is in a critical period of reform and development with profound transformations in the economic system, alterations in social structure, adjustment of the interest pattern and changes in ideas. As the basic unit of the economic society, enterprise is the practitioner and the promoter of the reform and development, which is undergoing the market-oriented reform of system mechanism, industrial structure, management operation and profit distribution. As ideological emancipation of people is the forerunner of all reforms and the unity of people's thinking is the guarantee of the reform, ideological and political education is the crucial determinant to the success or failure of the reform and the rise and fall of the business. Traditional ideological and political education is faced with challenges such as the diversified educational objects, the influx and collision of all kinds of ideological trends, the fickleness and utility of social climate and many others. Moreover, various issues such as obsolete educational methods, moderately low level of work specialization and lack of professionalization of practitioners still exist, restricting the effectiveness of ideological and political education. How to improve the professionalization, specialization and scientification of ideological and political education is the key to resolve problems of current ideological and political education.

This paper intends to build up a work model and provide a new way to ideological and political education for enterprises as human resource business partner(HRBP).

\section{Relationship between ideological and political education and human resource management}

Ideological and political education and human resource management are closely related to each other in terms of both theoretical foundation and work practice. Given the task background and the characteristics of staff in enterprises, ideological and political education and human resource management share highly compatible objectives, effectively complementary work means, and interdependent environments, and the integration of them will bring out huge force for the reform and development of the enterprise, speed up and protect the implementation of enterprise's strategy.

\section{Communality of work object.}

The object of ideological and political education and human resource management in enterprises is staff. According to the iceberg theory, the ideological and political education directly acts on morality, consciousness, attitude, value, inner drive and other covert quality parts of the iceberg. Human resource has been relatively mature in the development and management of knowledge, skills, behavior and other overt parts of the iceberg, and has been giving more and more emphasis on the development of the covert part of the iceberg. The structural characteristics, behavior pattern, value orientation, ideological status, emotional reactions, interest appeal and others of employees as 
a group are elements that should be considered in both ideological and political education and human resource management, which bring challenges to both of them.

\section{Consistency of work objective.}

The ideological and political education in enterprises mainly guides, influences and regulates the employees by means of theories, practices and other educational methods, such as policy principles, ideas and moral standards, so that employees may acquire the ideological quality, professional ethics and value culture needed by enterprises, and the internal drive force of work and the cohesive force of cooperation can be formed to promote enterprise development and performance. In short, the ideological and political education in enterprises is to serve the essential work of enterprises. The human resource management in enterprises is to effectively develop and rationally put staff into the right place through the scientific management theory, technology, methods and means, so as to achieve the coordinated development of enterprises and employees and meet enterprises' needs of business development and the implementation of business strategy. Obviously, centered on the survival and development of enterprises, the ideological and political education and human resource management share highly consistent work objectives.

\section{Connectivity of work content.}

Human nature, human needs and all-round development of human are part of the theoretical basis shared by both ideological and political education and human resource management. In enterprises, the main contents of the ideological and political education include "education on three outlooks", namely the outlook of the world, the life and the value, education on national and industrial policies, principles and regulations as well as education on professional ethics such as integrity, responsibility and cooperation. The main contents of the classic human resource management include planning and design, recruitment configuration, training and cultivation, compensation and benefits, performance management and employee relations. At the first glance, there are big differences between ideological and political education and human resource management. However, in-depth analysis shows that the corporate values and mission identity built up by ideological and political education is one of the core inputs of human resource strategic planning; education on policies, principles and regulations is one of the legal bases of the recruitment configuration, compensation and benefits and employee relations; and professional ethics education is an important content of the training and cultivation. In addition, from the perspective of the enterprise culture, the ideological and political education is an important part of enterprise culture building, and the highest level of human resource management is the cultural management. Therefore, the work content of the two has similarities.

\section{Complementarity of work means.}

As far as work methods and means are concerned, theoretical indoctrination, practical training, model demonstration, comparative identification, and self-education are all effective means of ideological and political education. Ideological and political education can be carried out through top-down publicity, but it influences and guides people's thinking and behavior in a more gentle and silent way. Human resource management mainly employs the tools of work analysis, index system, personality evaluation, merit rating and psychological analysis to develop and manage people's knowledge, skills, behavior, attitude, motivation and internal drive. Based on western management tools, these methods have distinctive features including institutionalization, process-based, standardization and streamlining. Therefore, the means of ideological and political education and human resource management, as a combination of hardness and softness, complement each other.

\section{Interdependency of work environment.}

Economic, political, cultural, social and other macro-environment as well as family, school, community, friends and other micro-environment have a significant and far-reaching impact on ideological and political education and human resource management. It can be said that the continuous development of ideological and political education and human resource management is driven by these environmental changes. When viewed from the internal environment of enterprises, strategic transformation, business adjustment, group variation, cultural change and so on bring similar challenges to the ideological and political education and human resource management, 
while the impacts brought about by ideological and political education and human resource management on enterprises' internal environment are interdependent. When ideological and political education is obviously effective, the staff is full of energy with unified values and strong cohesion, and the human resource management mechanism runs smoothly with favorable staff training, fewer labor conflicts and approved performance management, which helps achieve human resource management strategy. On the contrary, when the ideological and political education work is not effective, it is difficult to bring out concerted effort from staff because of the slack spirit, loose organization and disunified thought, and the strategy is hard to achieve as the difficulty of human resource management increases significantly.

\section{Work model of ideological and political education in enterprises as HRBP}

Under modern enterprise system, the vitality of ideological and political education and human resource management lies in serving the implementation of the strategy and core business of enterprises, and the focus of them lies in the impact on people. First of all, we should analyze the operating mechanism between enterprises' strategy and employees.

\section{Enterprise strategy operation model.}

At present, most enterprises have divorced the model of plan and task as the single driver under the planned economy era, and the formulation of enterprise strategy needs diversified input such as market demand, self-development and employee demands. The internal management of enterprises no longer relies solely on administrative instructions and documents, but through the process crossing business and departments to achieve the management of institutionalization, process-based and standardization, so that the rule of law can gradually replace the rule of man. With such a strategic drive and management approach, employees no longer simply perform tasks, but continuously improve their ability by integrating themselves into the operation mechanism of business strategy. Employees directly contribute to the enterprises' strategic objectives through performance promotion and at the same time they optimize business and management processes to serve enterprises' self-building through practices.

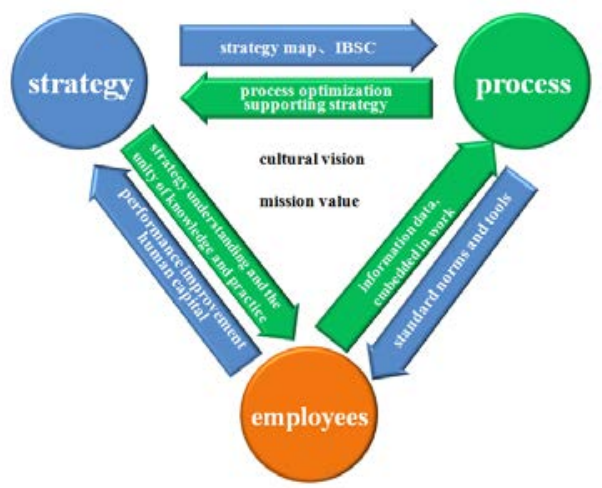

Figure 1 Enterprise Strategy Operation Model

From enterprise strategy operation model (Figure 1), the established enterprise strategy can be divided into specific business indicators and management indicators through strategy map, balanced scorecard and other tools. Then, with the indicators embedded in the business process and the implementation of management process, employees can carry out specific business and management activities based on the standard norms and tools provided by the process. Finally, employees contribute individual performance and improve their ability in work activities, leading to the improvement of organizational performance, the appreciation of human capital and ultimately the actualization of strategic objectives of enterprises. In turn, the established strategy can affect employees' strategy understanding and the unity of knowledge and practice through the ideological and political education and human resource management etc. In this way, employees can actively aim at enterprise strategy in specific work as well as accumulate and transmit information and data in the work process so as to promote the continuous improvement of the process and correct the implementation through process optimization and supporting strategy in order to achieve the 
implementation of the strategy. It can be seen that when "technical" elements such as strategy, process, responsibility, and skills are equal, employee's understanding of strategy, cultural identity, practice of values, internal drive to capacity enhancement and the initiative of process optimization are the key to the healthy and continuous operation of the system. These "non-technical" elements should be the focus of ideological and political education in enterprises and will open up a broad work space for ideological and political education to serve enterprises' core strategy and business.

\section{Model of role of ideological and political education as HRBP.}

Since the role and status of ideological and political education in the modern enterprise system has been made clear, what kind of role should ideological and political education play to meet the requirements of above-mentioned enterprise strategy operation mode? According to the needs of contemporary social development, the International Public Management Association for Human Resources has proposed that strategic human resource management should shift from a single personnel management to the management playing four roles including business partner, change promoter, leader and personnel management expert. The core of this shift is that HRM requires a keen perception of strategic and business changes and timely adjustments of HRM approaches and technologies to lead employees' ideas and behavior in the transformation through leadership and culture building so as to achieve the quick match with organizational strategy. In order to realize the effective integration of ideological and political education and human resource management, this paper proposes a model of ideological and political education as HRBP (shown in Figure 2). Ideological and political education should play the roles of culture builder, change promoter, HRBP and education expert.

\section{culture builder change promoter}

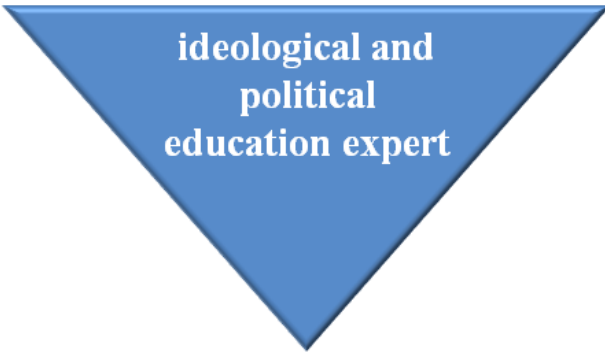

HRBP

Figure 2 Model of Ideological and Political Education as HRBP

(1) Ideological and political education expert: Ideological and political education should perform the traditional educational functions, organize education on dialectical materialism, historical materialism, socialism, principles and policies, global and national conditions, legal ethical concepts, etc. by using scientific education methods and cultivate a group of enterprise cadres and workers with firm belief, solid political stance and excellent quality for China's socialist construction.

(2) HRBP: ideological and political education should become a working partner of human resource. Specifically, ideological and political education should play a role in such human resource management functions as employee relationship management, performance management, training and development as well as recruitment and staffing, so as to improve the effectiveness of human resource management and provide ideological guarantee for strategic human resource management. The roles that it can play include: participating in employee retention, termination and reassignment to promote a harmonious relationship among employees; participating in performance feedback communication to improve employee performance; carrying out professional ethics, ideals and beliefs as well as dialectical philosophy training to enhance the ideological maturity of employees; and participating in the interview assessment and providing professional evaluation of the ideological character and moral qualities to promote the effectiveness and scientification of the cultural fit assessment. Furthermore, as the HRBP, ideological and political education helps to understand various activities of enterprises and the characteristics of the workforce, comprehend the dynamic thinking of employees and listen to employees' real demands so as to improve the 
pertinence of ideological and political education, implement the content thereof through human resource management methods and improve the scientification and professionalism of ideological and political education.

(3) Change promoter: ideological and political education should promote and guarantee the reform of enterprises. Any change in the enterprise will lead to changes in employee thinking. Employees with thinking and behavior paradigm will naturally resist changes, which may bring various obstacles for changes. Some resistance may be more intense, and even affect the normal production and operation of enterprises; some resistance may be more subtle, which is reflected in the decline in enthusiasm and work efficiency; some other resistance may be in the neutral zone, waiting for the situation to be gradually clear to become an advocate of or a resistant to changes. Whether the ideological and political education can create the atmosphere of change ahead of time and get employees mentally prepared for changes, whether it can play a strong ideological and political propaganda role in the face of fierce resistance and control the deterioration of the situation, and whether it can carry out effective ideological guidance in the neutral zone and make it the advocate for changes is key factor determining the advancement and success of change.

(4) Culture builder: ideological and political education should be the leader and builder of enterprise culture. Enterprise culture with enterprise values as its core is the soul and the core competitiveness of enterprises. Advanced enterprise culture is an important part for strengthening CPC's administrative competence, developing socialist advanced culture and building a harmonious socialist society. Ideological and political education as the enterprise culture builder is duty-bound. On the one hand, ideological and political education can help enterprises grasp the right direction and contribute to the organizational security of enterprise culture construction; on the other hand, enterprise culture construction can improve the effectiveness and sense of the times of ideological and political education and further promote the integration of ideological and political education and business strategy and the central work. Enterprise culture is the spiritual home of employees and the fertile ground producing shared values. The role that ideological and political education plays as the enterprise culture builder will create new work vehicles and hand grips for it and escort for the reform and development of enterprises.

Work model of ideological and political education in enterprises based on HRBP.

Through the analysis of the enterprise strategy operation model and the design of the model of the role of ideological and political education, we can deduce the work model of ideological and political education in enterprises as the HRBP (shown in Figure 3).

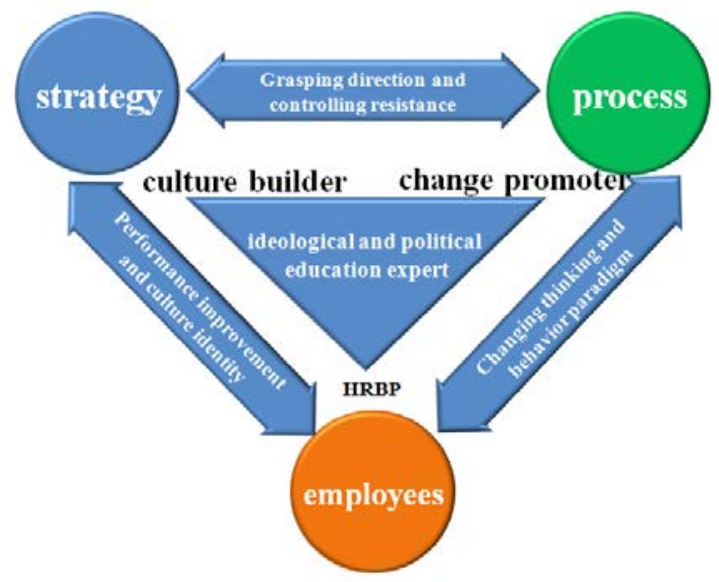

Figure 3 Work Model of Ideological and Political Education in Enterprises as HRBP

Ideological and political education strengthens the unified understanding of enterprise culture, mission, vision and values through its role of culture builder and education experts to guarantee the strategic formulation in line with the correct direction of change and development of enterprises. When the strategic goal is carried out through process operation, ideological and political education plays the role of the change promoter by creating the atmosphere of change, controlling the resistance to change, and guiding the way of change identification to change employees' thinking 
and behavior paradigm and ensure the improvement and adjustment of process in change. After that, ideological and political education, as a HRBP, participates in employees' performance management, training development, employee relationship, recruitment and staffing, etc. to answer employees' confusion, respond to employees' demands and imperceptibly affect employees' thinking, thus promoting employees' cultural recognition, improving employees' working status and stimulating employees' internal working drive. Finally comes to the transformation of thought to behavior so as to improve employee performance and organizational performance and carry out enterprise strategy. In the whole operation process of the work model, ideological and political education, by playing four roles and functions, focuses on enterprise culture, mission, vision and values to grasp the strategic direction, control change resistance, change thinking paradigm, improve personal performance and recognize organizational culture as well as to show a new vitality and value of ideological and political education.

\section{Conclusion}

This paper analyzes the problems and challenges faced by ideological and political education and human resource management in the process of enterprise transformation and development. By exploring the internal theoretical and practical relationship between ideological and political education and human resource management, this paper proposes that ideological and political education should play four such roles as education expert, culture builders, change promoter and HRBP, and designs a work model of ideological and political education as HRBP.

\section{References}

[1] Yu Miao. Discussion on the Integration of Ideological and Political Work and Enterprise Culture Construction in State-owned Enterprises, Beijing Institute of Technology, 2008.

[2] Li Jian. The Revelation of Maslow's Hierarchy of Needs Theory on Ideological and Political Work, Legal System and Society, 2008.

[3] Zhao Xia. The Revelation of Maslow's Hierarchy of Needs Theory on the Internalization of Ideological and Political Education, Northern Literature, 2012.

[4] Qin Xin. Applying Maslow's Hierarchy of Needs Theory to Innovate Enterprise Ideological and Political Work, The World of Enterprise, 2003.

[5] Jiang Xuexiang. Discussion on Employee Incentive Based on Maslow's Hierarchy of Needs Theory, Journal of Educational Science of Hunan Normal University, 2008.

[6] Yue Yunlin. The Revelation of Maslow's Hierarchy of Needs Theory to Enterprise Human Resource Management, Guide to Business, 2012.

[7] Guo Fangming. On the Application of Hierarchy of Needs Theory in Human Resource Management, Journal of The Managers, 2008.

[8] Luo Chengfa. On the Integration of Human Resource Management into Ideological and Political Education, Political Work Research Trends, 2005(21).

[9] Liu Xingeng. A New Probe into the Social Management Function of Ideological and Political Education, Probe, 2006(6).

[10] Huang Dongmei. Economic Analysis of Ideological and Political Education, Ideological \& Theoretical Education, 2006(7-8).

[11] Peng Jianfeng. Strategic Human Resource Management, China Renmin University Press, 2014(1). 